\title{
PENGARUH SUKU BUNGA, BIAYA, DAN PELAYANAN TERHADAP KEPUASAN NASABAH KREDIT MIKRO PADA BANK DANAMON SIMPAN PINJAM RANTAUPRAPAT
}

Ayuni Indasyari Tanjung ${ }^{1}$, Musdhalifah Zebua ${ }^{2}$

Alumni Sarjana Ekonomi STIE Labuhanbatu ${ }^{2}$ Dosen STIE Labuhanbatu

\begin{abstract}
ABSTRAK
Tujuan penelitian ini adalah untuk mendapatkan bukti empiris tentang pengaruh Suku Bunga, Biaya, dan Pelayanan terhadap Kepuasan Nasabah Kredit Mikro Pada Bank Danamon Simpan Pinjam Rantauprapat baik secara parsial maupun simultan. Jenis penelitian ini adalah penelitian asosiatif dan jenis data yang digunakan adalah data primer dan data sekunder. Teknik pengambilan sampel menggunakan metode Purposive Samplingdengan jumlah sampel sebanyak92 orang responden yang diperoleh dengan menggunakan rumus Slovin. Hasil penelitian ini menunjukkan bahwa Suku Bunga, Biaya, dan Pelayanan berpengaruh positif dan signifikan terhadap Kepuasan Nasabah Kredit Mikro pada Bank Danamon Simpan Pinjam Rantauprapat, baik secara parsial maupun simultan.Nilai Adjusted $R$ Square $\left(R^{2}\right)$ sebesar 0,643 berarti bahwa Kepuasan Nasabah Kredit Mikro pada Bank DanamonSimpan Pinjam Rantauprapat mampu dipengaruhi oleh Suku Bunga, Biaya, dan Pelayanan sebesar 64,3\%, sedangkan sisanya sebesar $35,7 \%$ dipengaruhi oleh faktor lain yang tidak dibahas dalam penelitian.
\end{abstract}

Kata Kunci : Suku Bunga, Biaya, Pelayanan, Kepuasan Nasabah.

konsumen atau pelanggan atas produk yang dikonsumsinya, jadi jelas bahwa tingkat kepuasan konsumen merupakan hal yang utama untuk mencapai tujuan perusahaan tadi walaupun sebenarnya banyak faktor yang mempengaruhi tingkat kepuasan tesebut.

Salah satu alasan mengapa usaha mencapai kepuasan pelanggan maksimum dan tidak pernah mengecewakan mereka itu penting adalah bahwa kita berada diera pelanggan, hanya perusahaan yang dapat mencapai kepuasan pelanggan yang optimum yang dapat bertahan dan berhasil.

Kebutuhan akan mendapatkan tingkat kepuasan konsumen berlaku bagisegalajenis sektor usaha tidak terkecuali dengan perusahaan perbankan yang menjual produk jasa kepada nasabah sebagai konsumennya. Untuk menjaga hubungan baik dengan nasabah maka kepuasan nasabah harus menjadi proritas

utama, karena kepuasan nasabah merupakan faktor utama terciptanya loyalitas terhadap perusahaan yang menjadi dasar pencapaian tujuan jangka panjang perusahaan yaitu kontiunitas perusahaan seperti yang disebutkan sebelumnya, konsumen adalah raja, nasabah adalah konsumen yang berpotensi sebagai pelanggan dari perusahaan perbankan yang berhak mendapatkan kepuasan atas konsumsi dari produk jasa yang dijual oleh perbankan. 
Sesuai kebutuhan bisnis saat ini perbankan mulai menjadikan sektor mikro sebagai core business (bisnis inti) target pasarnya, dimana sektor ini masih baru dan sangat potensial. Perusahaan perbankan pun berlomba-lomba membuka divisi untuk penyaluran kredit mikro, yang pada awalnya dimulai Bank BRI Unit (tahun 1988) dan tahun 2000-an diikuti bank-bank lainnya seperti Bank Danamon dengan divisi Danamon Simpan Pinjam (DSP), Bank Bukopin dengan divisi Swamitra, Bank Mandiri dengan divisi Mandiri Mikro, Bank Mega dengan divisi Mega Mitra dan lain-lain. Semakin kompetitifnya persaingan dalam hal ini memunculkan ide dan kreatifitas serta inovasi demi mendapatkan konsumen yaitu nasabah sebanyak mungkin, karena maju mundurnya perbankan salah satunya dipengaruhi oleh tingkat kuantitas nasabah yang dimiliki, namun keadaan ini sering memunculkan sikap pragmatis yang tidak memperdulikan tingkat kepuasan nasabah secara tidak langsung menjadi korban adalah nasabah sendiri.

Salah satu bank yang menjadi leader sekarang ini dalam kegiatan bisnis penyaluran kredit mikro adalah Bank Danamon Indonesia dengan bisnis SelfEmployment Mass Market (SEMM) ataulebih dikenal dengan Danamon Simpan Pinjam (DSP) yang dibentuk tahun 2004, segmen pasar ini terdiri dari bisnis usaha mikro/kecil dengan pinjaman kredit Rp 5 Juta hingga Rp 500 Juta. Saat ini DSP merupakan salah satu mesin penggerak utama kegiatan bisnis Danamon yang menyumbang 29\% terhadap total kredit portofolio Danamon dan juga berada pada posisi 3 besar dari sisi kontribusi terhadap profitabilitas Danamon. Dalam menyalurkan kredit mikronya dibagi atas dua jenis yaitu:

Jenis Pasar Model, dengan kriteria jangka waktu pinjaman maksimal 5tahundengan plafond Rp 5 juta - Rp 500 juta disertai dengan agunan atau jaminan kredit.

Jenis Solusi Modal, dengan kriteria jangka waktu pinjaman maksimal 3tahun,dengan plafond Rp 5 juta - Rp 50 juta, dengan pinjaman tanpa agunan atau jaminan kredit.

Untuk melengkapi variasi produknya dan menambah dana funding, Danamon Simpan Pinjam juga memiliki produk simpanan yaitu Tabungan Sipinter dan Deposito DSP. Biasanya kantor cabang dari Danamon Simpan Pinjam atau disebut unit berada dikawasan bisnis suatu daerah seperti pusat pasar daerah atau pasar-pasar tradisional di daerah tersebut, salah satu unit Danamon Simpan

Pinjamyang ada yaitu DSP Unit Rantauprapat yang berdiri pada tahun 2006. Sejak dibuka pada tahun 2006 perkembangan jumlah nasabah DSP Rantauprapat fluktuatif. Pada tahun 2011 jumlah nasabah aktifnya mencapai 1.395 orang, tahun 2012 bertambah menjadi 1.619 orang, tahun 2013 menurun secara signifikan menjadi 1.321 orang dan ditahun 2014 jumlah nasabah aktif tinggal 1.208 orang.

\section{Rumusan Masalah}

Berdasarkan latar belakang permasalahanyang telah diuraikan sebelumnya maka yang menjadi masalah utama dalam penelitian sebagai berikut : 
- Apakah suku bunga berpengaruh terhadap kepuasan nasabah kredit mikro pada Bank Danamon Simpan Pinjam Rantauprapat?;

- Apakah biaya berpengaruh terhadap kepuasan nasabah kredit mikro pada Bank Danamon Simpan Pinjam Rantauprapat?;

- Apakah pelayanan berpengaruh terhadap kepuasan nasabah kredit mikro pada Bank Danamon Simpan Pinjam Rantauprapat?;

- Apakah suku bunga, biaya, dan pelayanan berpengaruh terhadap kepuasan nasabah kredit mikro pada Bank Danamon Simpan Pinjam Rantauprapat?

\section{Tujuan Penelitian}

Berdasarkan uraian permasalahan di atas, adapun tujuan dari penelian ini adalah:

1. Untuk mengetahui pengaruh suku bungaterhadap kepuasan nasabah kredit mikro pada Bank Danamon Simpan Pinjam Rantauprapat;

2. Untuk mengetahui pengaruh biaya terhadap kepuasan nasabah kredit mikro pada Bank Danamon Simpan Pinjam Rantauprapat;

3. Untuk mengetahui pengaruh pelayanan terhadap kepuasan nasabah kredit mikro pada Bank Danamon Simpan Pinjam Rantauprapat;

4. Untuk mengetahui pengaruhsuku bunga, biaya, dan pelayanan terhadap kepuasan nasabah kredit mikro pada Bank Danamon Simpan Pinjam Rantauprapat.

\section{Manfaat Penelitian}

Adapun manfaat dari penelitian ini adalah :

1. Bagi penulis sendiri, hasil penelitian ini dapat menambah wawasan dan ilmu pengetahuan khususnya dalam hal pemberian kredit mikro.

2. Bagi perusahaan yang diteliti, sebagai bahan masukan akan pentingnya tingkat kepuasan serta faktor-faktor yang mempengaruhinya dalam pemberian kredit sehingga perusahaan dapat mengaplikasikannya, dan sebagai bahan perbandingan antara praktek yang telah dilaksanakan perusahaan selama inidengan teori-teori dan perkembangan ilmu pengetahuan yang ada.

3. Sebagai referensi bagi yang berminat melakukan penelitian berikutnya yang berhubungan dengan analisis kepuasan konsumen. 


\section{LANDASAN TEORI Uraian Teoritis}

Pemasaran dan Pemasaran Jasa pemasaran sebagai proses perencanaan dan pelaksanaan konsepsi, penetapan harga, promosi serta distribusi gagasan, barang dan jasa untuk menciptakan pertukaran yang memuaskan tujuan individual dan organisasional.

Konsep Kepuasan Konsumen kepuasan atau ketidakpuasan konsumen adalah respon konsumen terhadap evaluasi ketidaksesuaian yang dirasakan antara harapan sebelumnya (normal kineja lain) dan kinerja aktual produk yang dirasakan setelah pemakaiannya.

Suku Bunga suku bungamerupakan harga produk jasa yang harus dibayar nasabah kepada bank sebagai balas jasa berdasarkan prinsip konvensional atas manfaat, penggunaan (konsumsi) terhadap produk jasa bank.

\section{Biaya}

Biaya adalah semua pengorbanan yang perlu dilakukan untuk suatu proses produksi, yang dinyatakan dengan satuan uang menurut harga pasar yang berlaku.

\section{Pelayanan}

Pelayanan sebagai akifitas atau serangkaian aktifitas yang bersifat tidak kasat mata (tidak dapat diraba) yang terjadi sebagai akibat adanya interaksi antara konsumen dengan karyawan yang mencakup hal-hal lain yang disediakan oleh perusahaan pemberi jasa, yang dimaksud untuk memecahkan masalah konsumen.

\section{Kerangka Konseptual}

Berdasarkan teori yang mendasari penelitian ini serta pengamatan langsung dilapangan,penulis dapat menyusun kerangka pemikiran dalam penelitian iniseperti digambarkan sebagai berikut 
$\left(\mathbf{X}_{1}\right)$

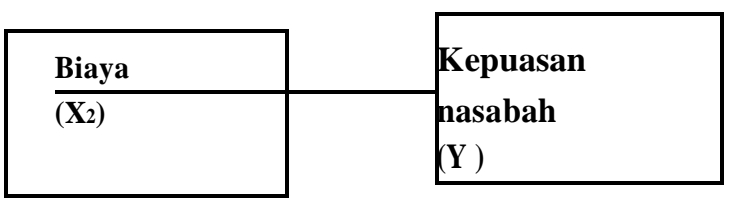

Pelayanan

(X3)

\section{Gambar 2.1 Kerangka Konseptual}

\section{Hipotesis}

Hipotesis merupakan jawaban sementara berdasarkan rumusan masalah yangkebenarannya perlu diuji secara ilmiah. berdasarkan kerangka konseptual yang sudahdikemukakan di atas maka penulis merumuskan hipotesis sebagai berikut :

1. Suku bunga berpengaruh positif dan signifikan terhadap kepuasan nasabah kredit mikro pada Bank danamon Simpan Pinjam Rantauprapat;

2. Biaya berpengaruh positif signifikan terhadap kepuasan nasabah kredit mikro pada Bank Danamon Simpan Pinjam Rantauprapat;

3. Pelayanan berpengaruh positif dan signifikan terhadap kepuasan nasabah kredit mikro pada Bank Danamon Simpan Pinjam Rantauprapat;

4. Suku bunga, biaya, dan pelayanan berpengaruh positif dan signifikan terhadap kepuasan nasabah kredit mikro pada Bank Danamon Simpan Pinjam Rantauprapat.

\section{METODE PENELITIAN}

\section{Populasi}

Adapun yang menjadi populasi dalam penelitianini adalah para nasabahDanamon Simpan Pinjam Unit Rantauprapat dengan jumlah nasabah aktif hingga Desember 2014 sebanyak 1.208 orang.

\section{Sampel}

Metode pemilihan sampel menggunakan metode ProbabilitySamplingkarenasetiap unsur populasimemiliki peluang yang sama untuk dijadikan anggotasampeldengan teknik Simple Random Sampling dimana sampeldiambil secaraacak danpopulasi dianggap homogen (yaitu nasabah kredit mikro). 
Rumus yang digunakan dalam

penentuanjumlah sampel adalah RumusSlovin(Situmorang dkk, 2009:132), yaitu:

$\mathrm{Nn}$

$=$

2

$(1+\mathrm{Ne})$

Keterangan $: \mathrm{n}=$ jumlah sampel $\mathrm{N}=$ ukuran populasi $e=$ margin error $(10 \%$ atau 0,1$)$ Sehingga Jumlah Sampel (n) menjadi : $n$

$$
\begin{gathered}
=\frac{1208}{\left(1+1208(0,1)^{2}\right)} \\
n=92,35 \approx 92 \text { orang. }
\end{gathered}
$$

Dengandemikian, jumlah sampel penelitian adalah sebanyak 92 orang.

\section{Teknik Pengumpulan Data}

Adapun teknik pengumpulan data dalam penelitian ini yaitu :

1.Observasi

2.Wawancara

3.Kuesioner

\section{Metode Analisis Data}

- Metode Analisis Deskriptif

- Metode Analisis Statistik

- Metode analisis Statistik yang digunakan adalah :

- Uji Asumsi Klasik

- Uji Normalitas

- Uji Multikoliniearitas 
- Uji Heteroskedastisitas

- Analisis Regresi Linear Berganda

- Uji Hipotesis

- Uji Signifikansi Parsial (Uji t)

- Uji Signifikansi Simultan (Uji F)

- Koefisien Determinasi $\left(R^{2}\right)$

\section{HASIL PENELITIAN Pengujian Hipotesis}

Hipotesis pada penelitian ini diuji dengan menggunakan uji signifikansi parsial (Uji t), uji signifikansi simultan (Uji F), dan koefisien determinasi $\left(R^{2}\right)$.

Uji Signifikansi Parsial (Uji t)

Uji t ini menunjukkan seberapa besar pengaruh variabel bebas $(\mathrm{X})$ secara parsial/individu terhadap variabel terikat

(Y). Uji t dilakukan dengan cara membandingkan nilai thitung dengan tabeldengan kriteria pengambilan keputusan adalah :

Ho diterima jika thitung $<$ tabel pada $\alpha=5 \%$.

Ha diterima jika thitung > tabel pada $\alpha=5 \%$.

Nilai thitung diperoleh dengan menggunakan software SPSS 20.0 for Windows, kemudian akan dibandingkan dengan nilai tabel pada tingkat $\alpha=5 \%$ yakni yang diperoleh dengan derajat bebas $=\mathrm{df}-\mathrm{k}(\mathrm{df}$

jumlah sampel dan $\mathrm{k}=$ jumlah variabel keseluruhan) yaitu df1

4-1 = 3, dan df $2=92-4=88$. uji thitung yang dilakukan adalah uji dua arah maka tabel yang digunakan adalah t $5 \%$ atau $\mathrm{t} 0,05(88)=1,662$. 


\section{Tabel 1 Hasil}

\section{Uji Parsial (Uji t)}

\section{Coefficients $^{\mathrm{a}}$}

\begin{tabular}{|l|l|l|}
\hline Model & $t$ & Sig. \\
\hline Constant) &, 780 &, 437 \\
Suku bunga & 6,901 &, 000 \\
1 & 5,735 &, 000 \\
Biaya & & \\
Pelayanan & 2,029 & 045 \\
\hline
\end{tabular}

a. Dependent Variable: Kepuasan nasabah

Berdasarkan Tabel 1 maka dapat dijelaskan sebagai berikut :

Suku bunga $\left(\mathrm{X}_{1}\right)$ berpengaruh secara positif dan signifikan terhadap kepuasan nasabah $(\mathrm{Y})$, hal ini dilihat dari nilai signifikan $0,000<0,05$ dannilai thitung $(6,901)>$ tabel $(1,662)$. Dengan demikian hipotesis dapat diterima.

Biaya $\left(\mathrm{X}_{2}\right)$ berpengaruh secara positif dan signifikan terhadap kepuasan nasabah (Y), hal ini dilihat dari nilai signifikan $0,000<0,05$ dannilaithitung $(5,735)>$ tabel $(1,662)$. Dengan demikian hipotesis dapat diterima.

Pelayanan $\left(\mathrm{X}_{3}\right)$ berpengaruh secara positif dan signifikan terhadap kepuasan nasabah $(\mathrm{Y})$, hal ini dilihat dari nilai signifikan $0,045<0,05$ dannilaithitung $(2,029)>$ tabel $(1,662)$. Dengan demikian hipotesis dapat diterima. Dengan demikian hipotesis dapat diterima.Uji Signifikansi

\section{Simultan (Uji F)}

Uji F (uji serentak) dilakukan untuk

melihatsecara bersama-sama

pengaruhatauhubungan positif dan signifikan variabel bebas $\left(\mathrm{X}_{1}, \mathrm{X}_{2}\right.$, dan $\left.\mathrm{X}_{3}\right)$ berupa variabel suku bunga, biaya, dan pelayanan dan variabel terikat (Y) berupa kepuasannasabah kredit mikro Bank Danamon Simpan Pinjam Rantauprapat.

Kriteriapengambilan keputusan adalah :

Ho diterima jika Fhitung $<$ Ftabel pada $\alpha=5 \%$.

Ha diterima jika Fhitung $>$ Ftabel pada $\alpha=5 \%$. 
Nilai Fhitung diperoleh dengan menggunakan software SPSS 20.0 forWindows, kemudian akan dibandingkandengan nilai Ftabel pada tingkat $\alpha=5 \%$ dengan derajat bebas yaitu df1 $=4-1=3$, dan df $2=92-4=88$. Maka Ftabel yang digunakan adalah nilai $F_{0,05}(3: 88)=2,71$.

\section{Tabel 2 Hasil Uji}

\section{Simultan (Uji F)}

ANOVA $^{\text {a }}$

\begin{tabular}{|c|c|c|c|c|c|}
\hline Model & $\begin{array}{l}\text { Sum of } \\
\text { Squares }\end{array}$ & df & $\begin{array}{l}\text { Mean } \\
\text { Square }\end{array}$ & $\mathrm{F}$ & Sig. \\
\hline Regression & 140,082 & $\beta_{88}^{3}$ & $\begin{array}{l}46,694 \\
838\end{array}$ & 55,696 & $000^{\mathrm{b}}$ \\
\hline Total & 213,859 & 91 & & & \\
\hline
\end{tabular}

Dependent Variable: Kepuasan nasabah

Predictors: (Constant), Pelayanan, Biaya, Suku bunga

Berdasarkan Tabel 2 bahwa nilai

Fhitung $>$ Ftabel $(55,696>2,71)$ dengan taraf signifikansi $0,000<0,05$ menunjukkan bahwa suku bunga, biaya dan pelayanan secara serempak atau bersama-sama

berpengaruh signifikanterhadap

kepuasan nasabah kredit mikro Bank Danamon Simpan Pinjam Rantauprapat.

Koefisien Determinasi $\left(\boldsymbol{R}^{2}\right)$ Pengujian koefisien determinasi

$\left(R_{2}\right)$ bertujuan untuk mengetahui seberapabesar kemampuan variabel bebas menjelaskan variabel

terikat.

Dalamoutput SPSS,koefisien determinasi terletak pada tabel Model Summary dan tertulis $R$ Square.Namun untuk regresi linear berganda sebaiknyamenggunakan nilai $R$ Square yang sudahdisesuaikan atau tertulis Adjusted $R$ Square, karena disesuaikan dengan jumlahvariabel bebas dalam penelitian. Nilai $R$ Square dikatakan baik jika di atas 0,5 karenanilai $R$ Square berkisar antara 0 sampai 1.

\section{Tabel 3 Koefisien}




\section{Determinasi}

Model Summary
\begin{tabular}{|l|l|l|l|l|}
\hline Model & $\mathrm{R}$ & $\mathrm{R}$ & $\begin{array}{l}\text { Adjusted R } \\
\text { Square }\end{array}$ & $\begin{array}{l}\text { Std. Error } \\
\text { of the } \\
\text { Estimate }\end{array}$ \\
\hline 1 &, $809^{\mathrm{a}}$ & 655 & 643 & 916 \\
\hline
\end{tabular}

a. Predictors: (Constant), Pelayanan, Biaya, Suku bunga

Dari tabel 3 terlihat nilai $R=0,809$, berarti hubungan antara suku bunga, biaya, dan pelayanan terhadap kepuasan

nasabah sebesar 80,9\%, artinyahubungannya sangat erat. Adapun nilai Adjusted $R$ Square $=$ 0,643, berarti 64,3\% kepuasan nasabah dapat dijelaskan oleh suku bunga, biaya, dan pelayanan sedangkan sisanya $(35,7 \%)$ dapat dijelaskan faktor-faktor lainyangtidak tidak dijelaskan dalam penelitian ini.

\section{KESIMPULAN}

Berdasarkan hasil analisis yang telah dilakukan, maka dapat diambil beberapa kesimpulan sebagai berikut:

- Suku bunga secara parsial berpengaruh positif dan signifikan terhadap kepuasan nasabah kredit mikro pada Bank Danamon Simpan Pinjam Rantauprapat, dimana hasil penelitian menunjukan nilai thitung $(6,901)>$ tabel $(1,662)$ dengan taraf signifikan 0,000 $<0,05$.

Biaya secara parsial berpengaruh positif dan signifikan terhadap kepuasan nasabah kredit mikro pada Bank Danamon Simpan Pinjam Rantauprapat, dimana hasil penelitian menunjukannilaithitung $(5,735)>$ ttabel $(1,662)$ dengan taraf signifikan $0,000<0,05$.

Pelayanan secara parsial berpengaruh positif dan signifikan terhadap kepuasan nasabah kredit mikro pada Bank Danamon Simpan Pinjam Rantauprapat, dimana hasil penelitian menunjukan nilaithitung $(2,029)>$ tabel $(1,662)$ dengan taraf signifikan $0,045<0,05$.

Suku bunga, biaya, dan pelayanan secara serempak berpengaruh positif dan signifikan terhadap kepuasan nasabah kredit mikro pada Bank Danamon Simpan Pinjam Rantauprapat, dimana hasil penelitian menunjukan nilaiFhitung $>F_{\text {tabel }}(55,696>2,71)$ dengan taraf signifikan $0,000<$ 0,05 . 


\section{DAFTAR PUSTAKA}

Kuncoro, Mudrajad. 2009. Metode Riset untuk Bisnis \& Ekonomi (Edisi 3).

Jakarta : Erlangga.

Lolita, Erni. 2005. “Analisis FaktorFaktor Kepuasan Konsumen Studi Kasus

Usaha Makanan Mie Aceh Titi Bobrok”, Skripsi : Fakultas Ekonomi USU (Tidak

Dipublikasikan).

Lupiyoadi, Rambat. 2008. Manajemen PemasaranJasa, Edisi kedua, Cetakan keempat.Jakarta: Salemba Empat. Program SPSS.Semarang : Badan

Penerbit Universitas Diponegoro.

Sembiring, Arif Putranta Felix. 2014. "Pengaruh Tingkat Suku Bunga,

Kualitas Pelayanan, Dan Produk Terhadap Minat Masyarakat Pada Produk Kupedes PT BRI Unit

Simalingkar". Jurnal Ekonomi dan Bisnis. Vol. 2 No. 5.

Situmorang, Syafrizal Helmi dan Ginting, Paham. 2009. Analisis Data Penelitian.

Cetakan Kedua. Medan : USU Press.

Tjiptono, Fandy. 2005. Pemasaran Jasa. Edisi $\quad$ I. $\quad$ Malang ～: Bayumedia Pubishing.

Usman, Hardius dan Nurdin Sobari. 2013. Aplikasi Teknik Multivariate untuk

Riset Pemasaran. Jakarta: PT. RajaGrafindo Persada. 